\title{
A Retrospective Case-Control Study of Lipid Profiles in Carcinoma Breast in Comparison with Normal Controls
}

\section{Gurushantappa Yalagachin and Praveena S}

${ }^{1}$ Department of Surgery, Karnataka Institute of Medical Sciences, Hubli, Karnataka, India

${ }^{2}$ Department of Urology, NU hospitals, Bengaluru, India

\begin{abstract}
Introduction: Breast cancer is the second most common cancer in the world. One of the reasons for its increasing prevalence, especially in younger women has been attributed to lifestyle changes. All these factors also have a strong association with lipid metabolism. More evidence is coming forward to emphasise the protective effect of lifestyle modification to lower lipid levels and thus decreasing the risk of breast cancer.
\end{abstract}

Methods: It is a retrospective, case control study. The patients with carcinoma breast and normal controls were taken as subjects. The data for this study includes clinical profile and lipid profile measured in early morning fasting sample of the subjects. The patients of carcinoma breast, normal control aged $>18$ years were included, while patients with diabetes, thyroid disorders, on treatment for hyper-lipidaemia, dieting or anorexic, pregnant patients were excluded.

Results: There was no statistically significant differences in age $(p=0.920)$ and BMI $(p=0.137)$ between study and normal control group. Total Cholesterol (TC) and Triglycerides (TG) levels were significantly elevated ( $p=0.009$ and 0.000 respectively) in carcinoma breast group compared to normal controls, however no significant differences $(\mathrm{p}>0.05)$ observed in the levels of HDL-C, LDL-C.

Conclusions: There is a significant alteration in lipid metabolism in carcinoma breast patients in comparison to normal controls.

Key words: carcinogenesis; diet; estrogen; peroxidation

Correspondence: Praveena S, Department of Urology, NU hospitals, Bengaluru, India. emailpraveenas82@gmail.com

DOI: $10.3126 / \mathrm{mjsbh} . v 20 \mathrm{i} 2.31755$

Submitted on: $2020-10-03$

Accepted on: 2021-06-20

This work is licensed under creative common license:

http://creativecommons.org/licenses/by-nc-nd/4.0/ C MJSBH 2020 


\section{INTRODUCTION}

Breast cancer is the second most common cancer in the world only second to lung cancer and the most frequent cancer among women with an estimated incidence of 1.67 million in $2012(25 \%$ of all cancers) and its prevalence is constantly increasing in developing countries particularly in younger ladies. ${ }^{1,2}$ One of the contributing factors is the westernisation of lifestyle in these countries. ${ }^{2}$

There are multiple mechanisms by which lipid metabolism can affect carcinogenesis.Excessive intake of lipids promotes cancer development by inducing an inflammatory response, reduction in cancer cell apoptosis, increment in cell proliferation and angiogenesis. ${ }^{3}$ Excessive lipid intake increases the expression of $\beta$-scavenger receptor (CD36), a member of cell surface fatty acid receptors. Clinically, inhibition of CD36 reduces the metastasis of human melanoma and breast cancer. ${ }^{4-6}$ Abnormal levels of lipids are intimately related to carcinogenesis and cancer metastasis. Studies have shown that plasma levels of TC, TG, HDL-C, and LDL-C of breast cancer patients were significantly higher than that of the control group. 7,8

SREBP cleavage-activating protein (SCAP) is the key glucose-responsive protein serving as the oncogenic signalling hub and fuelling for SREBPdependent lipogenesis leading to invasiveness and metastasis of breast cancer.. 9,10 Compared with normal cells, the expression of Fatty Acid Synthase (FASN) is higher in breast cancer among many. ${ }^{11-13}$ More importantly, during the termination step various small molecules are produced, which induce oncogenic mutations and activate oncogenic pathways, promoting carcinogenesis. ${ }^{14,15}$ Some studies have reported that a high-fat diet can result in increased estrogen concentrations in the serum, potentially through increased de novo synthesis. ${ }^{16}$ Some other studies elucidated that the histopathological markers - estrogen receptor (ER), progesterone receptor (PR) and human epidermal growth factor receptor 2 (HER2/neu) expression) are frequently associated with breast cancer. ${ }^{17,18}$ The aim of this study is to study association of lipid and clincial profile between the patients diagnosed with breast cancer and normal controls.

\section{METHODS}

The present study is a case-control study, conducted among female patients with carcinoma breast, as cases and normal patients attending outpatient and inpatient department of general surgery at our hospital from 1st December 2016 to 31 st May 2018 as controls. The female patients of carcinoma breast with age more than 18 years were enrolled as cases (Group-1). The patients who do not have breast related illnesses, but attended the department for some other illness were taken as normal controls (Group-2). The patients with diabetes, thyroid disorders, on treatment for hyperlipidaemia, dieting or anorexic, pregnant, unwilling to participate in the study were excluded from the study. Institutional ethical committee clearance was obtained prior to the starting of the study. The minimum sample size was calculated to be 36 for cases and 36 for control group based on a standard formula by Kelsey et al. ${ }^{19}$ This was arrived at by assuming two-sided confidence level (1-alpha) of $95 \%$, power of the test at $80 \%$, hypothetical exposure in cases and controls to be $52 \%$ and $20 \%$ respectively. ${ }^{20}$ After taking informed consent, comprehensive history was noted. Relevant examination was done, including that of breast and axilla. Height and weight of subjects were recorded. Lipid profiles of all study subjects were estimated with early morning fasting (minimum of eight hours) venous blood sample at the same centralised laboratory, using Dade Behring Dimension RXL Chemistry Analyzer ${ }^{\mathrm{TM}}$ with the manufacturer provided cartridges. Results were analysed by Independent sample t-test using IBM $^{\circledR}$ SPSS $^{\circledR}$ Statistics software v23. Results are considered as statistically significant if p-value $<$ 0.05 .

\section{RESULTS}

Composition of study population: A total of 85 patients qualified to be study subjects of which carcinoma breast cases were 43 and normal control subjects were 42 . Out of 43 cases of carcinoma breast one subject had bilateral carcinoma breasts. All of them presented with lump in the breast while the duration of symptoms varied from 15 days to two years. One lady had a personal history of carcinoma breast and none had a positive family history. Average age at menarche was 12.6 years and average parity was 2.4. There were seven 
Table 1. Relevant clinical profile of cases of carcinoma breast

\begin{tabular}{|c|c|c|}
\hline \multicolumn{2}{|l|}{ Character } & $\begin{array}{c}\text { Number of } \\
\text { cases }\end{array}$ \\
\hline \multicolumn{2}{|c|}{ Tobacco consumption } & 3 \\
\hline \multicolumn{2}{|c|}{ Alcoholics } & 0 \\
\hline \multicolumn{2}{|c|}{ Positive family history } & 0 \\
\hline \multirow{3}{*}{$\begin{array}{l}\text { Menopausal } \\
\text { status }\end{array}$} & Pre-menopausal & 18 \\
\hline & Post-menopausal & 22 \\
\hline & Couldn't be assessed & 3 \\
\hline \multirow[t]{2}{*}{ Parity } & Nully parous & 7 \\
\hline & Parous & 36 \\
\hline \multirow[t]{4}{*}{ Clinical stage } & Stage I & 0 \\
\hline & Stage II & 13 \\
\hline & Stage III & 26 \\
\hline & Stage IV & 4 \\
\hline
\end{tabular}

nulliparous women and one parous woman who did not breastfeed. There were 18 pre-menopausal and 22 post-menopausal women with average age of menopause at 44.9 years. Menopausal status of three women could not be assessed as they had undergone hysterectomy. Three of them were tobacco chewers and none consumed alcohol. Their average weight was $55.1 \mathrm{~kg}$ while average height was $1.51 \mathrm{~m}$. Average tumour size was $6.1 \mathrm{~cm}$, while none had multiple lumps in the same breast (Table $1)$.

Age distribution of study subjects: Age of the subjects varied from 18 to 70 years. The average age of cases was 48 years, while it was 48.3 years in Normal control group (Figure 1, Table 2).

BMI distribution of study subjects: BMI of subjects varied from 13.82 to $32.02 \mathrm{~kg} / \mathrm{m}^{2}$. The average BMI of cases was $23.96 \mathrm{~kg} / \mathrm{m}^{2}$, while that of normal control group was $22.82 \mathrm{~kg} / \mathrm{m}^{2}$ (Table 3 , Figure 2).

Table 2. Age distribution and its significance among study subjects

\begin{tabular}{|l|r|r|r|r|}
\hline \multicolumn{1}{|l|}{ Group } & \multicolumn{1}{c}{ N } & \multicolumn{1}{c}{ Mean } & \multicolumn{1}{c}{ SD } & p-value \\
\hline 1 & 43 & 48.00 & 12.906 & 0.920 \\
\hline 2 & 42 & 48.31 & 15.176 & \\
\hline
\end{tabular}

Carcinoma Breast Normal Control

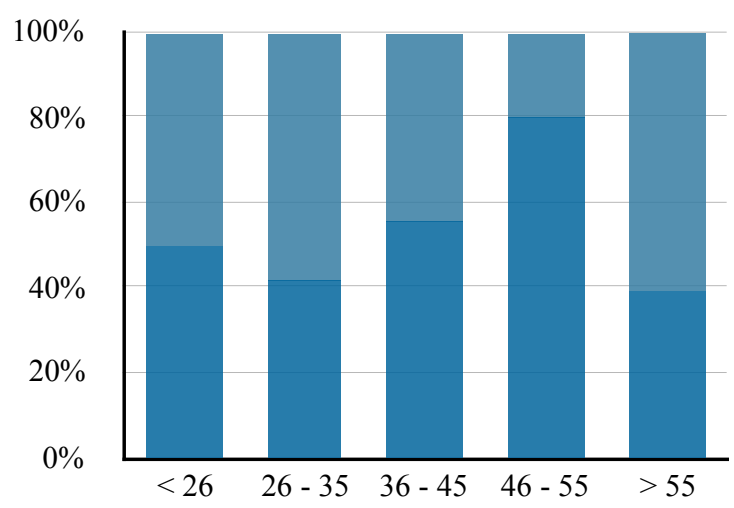

Figure 1. Age distribution of study subjects in percentages

Lipid profiles in the carcinoma breast group (Group-1): Of total 43 subjects, five (11.6\%) had elevated TC levels with mean level of $179.67 \mathrm{mg} /$ dl, 23 (53.5\%) had elevated TG levels with mean level of $197.67 \mathrm{mg} / \mathrm{dl}$, five $(11.6 \%)$ had decreased HDL-C levels with mean level of $39.16 \mathrm{mg} / \mathrm{dl}$ and five $(11.6 \%)$ had elevated LDL-C levels with mean level of $103.58 \mathrm{mg} / \mathrm{dl}$.

Lipid profiles in the normal control group (Group-2): Of total 42 subjects none $(0 \%)$ had elevated TC levels with mean level of $150.21 \mathrm{mg} /$ $\mathrm{dl}$, five (11.9\%) had elevated TG levels with mean level of $126.93 \mathrm{mg} / \mathrm{dl}$, seven $(16.7 \%)$ had decreased HDL-C levels with mean level of $37.62 \mathrm{mg} / \mathrm{dl}$ and three $(7.1 \%)$ had elevated LDL-C levels with mean level of $90.67 \mathrm{mg} / \mathrm{dl}$ (Figure 3).

Normal Controls

Carcinoma Breast

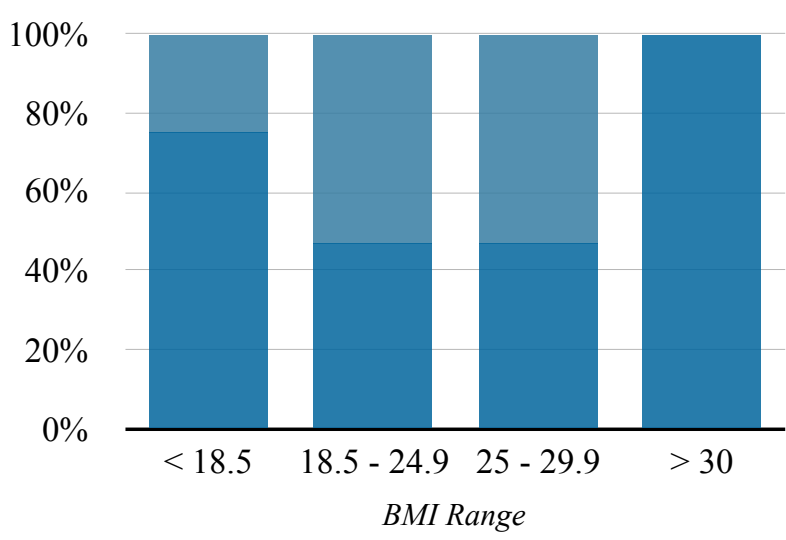

Figure 2. BMI distribution of study subjects in percentages 
Table 3. BMI distribution its significance among study subjects.

\begin{tabular}{|c|c|c|c|c|}
\hline Group & $\mathbf{N}$ & $\begin{array}{c}\text { Mean } \\
(\mathrm{kg} / \mathrm{m} 2)\end{array}$ & SD & p-value \\
\hline 1 & 43 & 23.96 & 3.82 & \multirow[t]{2}{*}{0.137} \\
\hline 2 & 42 & 22.82 & 3.14 & \\
\hline
\end{tabular}

Comparison of lipid profiles among study and control groups: The levels of TC $(\mathrm{p}-$ value $=0.009)$ and TG $(\mathrm{p}-$ value $=0.000)$ were significantly $(\mathrm{p}$ value $<0.05$ ) elevated in carcinoma breast group compared to normal control group, while other lipid levels such as HDL-C $(p-$ value $=0.920)$ and LDL-C ( $p$ value $=0.920)$ were not significantly different between the same groups (Table 4,5 ).

\section{DISCUSSION}

As it has been described in earlier, there is an association between altered lipid metabolism and the genesis of carcinoma breast. ${ }^{21}$ The physiological mechanisms involved in this process are not only diverse but also very complex. ${ }^{21,22}$ While many studies have elucidated that carcinoma breast patients will have deranged lipid levels compared to normal individuals, there are lacunae in the evidence to prove the causative role of lipid metabolism in carcinogenesis of the breast. ${ }^{20,23}$ Our study intended to find out the relation of the altered lipid profile in carcinoma breast patients in comparison to normal controls.

Upon analysing the results of our study we have found that there were no statistically significant

Carcinoma Breast

Normal control

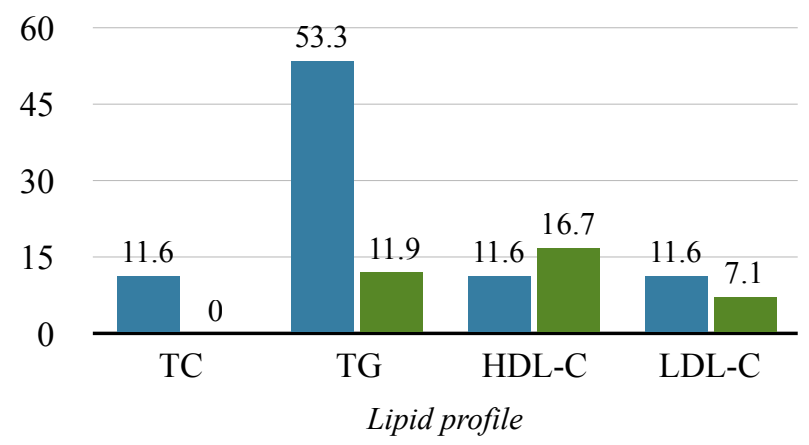

Figure 3. Percentage of subjects with deranged lipid profile in all study groups
Table 4. Percentage of subjects with abnormal lipid levels in various study groups

\begin{tabular}{|l|l|r|r|}
\hline $\begin{array}{l}\text { Lipid } \\
\text { profile }\end{array}$ & $\begin{array}{c}\text { Referenc } \\
\text { e range } \\
\text { (mg/dl) }\end{array}$ & \multicolumn{2}{|c|}{$\begin{array}{r}\text { Percentage of subjects with } \\
\text { deranged parameter } \\
\text { (actual number of sulbjects } \\
\text { in parenthesis) }\end{array}$} \\
\hline TC & $130-250$ & $11.6(5)$ & $0(0)$ \\
Group-1 & $\begin{array}{l}\text { Group-2 } \\
\mathrm{N}=43\end{array}$ \\
\hline TG & $50-170$ & $53.5(23)$ & $11.9(5)$ \\
\hline HDL-C & $30-75$ & $11.6(5)$ & $16.7(7)$ \\
\hline LDL-C & $70-140$ & $11.6(5)$ & $7.1(3)$ \\
\hline
\end{tabular}

differences in baseline characteristics such as age $(\mathrm{p}$ value $=0.920)$, BMI $(\mathrm{p}$ value $=0.137)$ between the carcinoma breast group and the normal control group, making the two groups comparable. The levels of TC $(\mathrm{p}$ value $=0.009)$ and TG $(\mathrm{p}$ value $=$ 0.000 ) were significantly ( $p$ value $<0.05$ ) elevated in carcinoma breast group compared to normal control group, while other lipid levels such as HDL-C $(\mathrm{p}$ value $=0.920)$ and LDL $-\mathrm{C}(\mathrm{p}$ value $=$ 0.920 ) were not significantly different between these groups.

In a similar case-control study by Anoop et al. where lipid profiles of carcinoma breast patients were compared with that of normal controls and patients of benign breast diseases, with 35 subjects in each group found that TG were significantly elevated in carcinoma breast group in comparison to either of the control groups. ${ }^{24}$ While there was no significant difference observed in other lipid parameters between the groups. Another casecontrol study by Franky et al compared the lipid

Table 5. Highlighting significant changes $(p<0.05)$ between carcinoma breast group and normal control group of our study in comparison to other published

\begin{tabular}{|l|l|l|l|l|}
$\begin{array}{l}\text { Lipid } \\
\text { profile }\end{array}$ & $\begin{array}{c}\text { Our } \\
\text { study } \\
\mathrm{N}=43 \text { vs } \\
42\end{array}$ & $\begin{array}{l}\text { Anoop et } \\
\text { al. 24 }\end{array}$ & $\begin{array}{l}\text { Franky et } \\
\text { al. 23 }\end{array}$ & $\begin{array}{l}\text { Pikul et } \\
\text { al. 25 }\end{array}$ \\
$\mathbf{N}=125$ vs & $\begin{array}{l}\text { N=249 } \\
\text { vs 154 }\end{array}$ \\
\hline TC & Elevated & $\begin{array}{l}\text { No } \\
\text { difference }\end{array}$ & Decreased & $\begin{array}{l}\text { No } \\
\text { difference }\end{array}$ \\
\hline TG & $\begin{array}{llll}\text { Elevated } \\
\text { Elevated }\end{array}$ & $\begin{array}{l}\text { Elevated } \\
\text { Elevated }\end{array}$ \\
\hline HDL-C & $\begin{array}{l}\text { No } \\
\text { difference } \\
\text { difference }\end{array}$ & Decreased & $\begin{array}{l}\text { No } \\
\text { difference }\end{array}$ \\
\hline LDL-C & $\begin{array}{l}\text { No } \\
\text { difference }\end{array}$ & $\begin{array}{l}\text { No } \\
\text { difference }\end{array}$ & $\begin{array}{l}\text { No } \\
\text { difference }\end{array}$ & Elevated \\
\hline
\end{tabular}




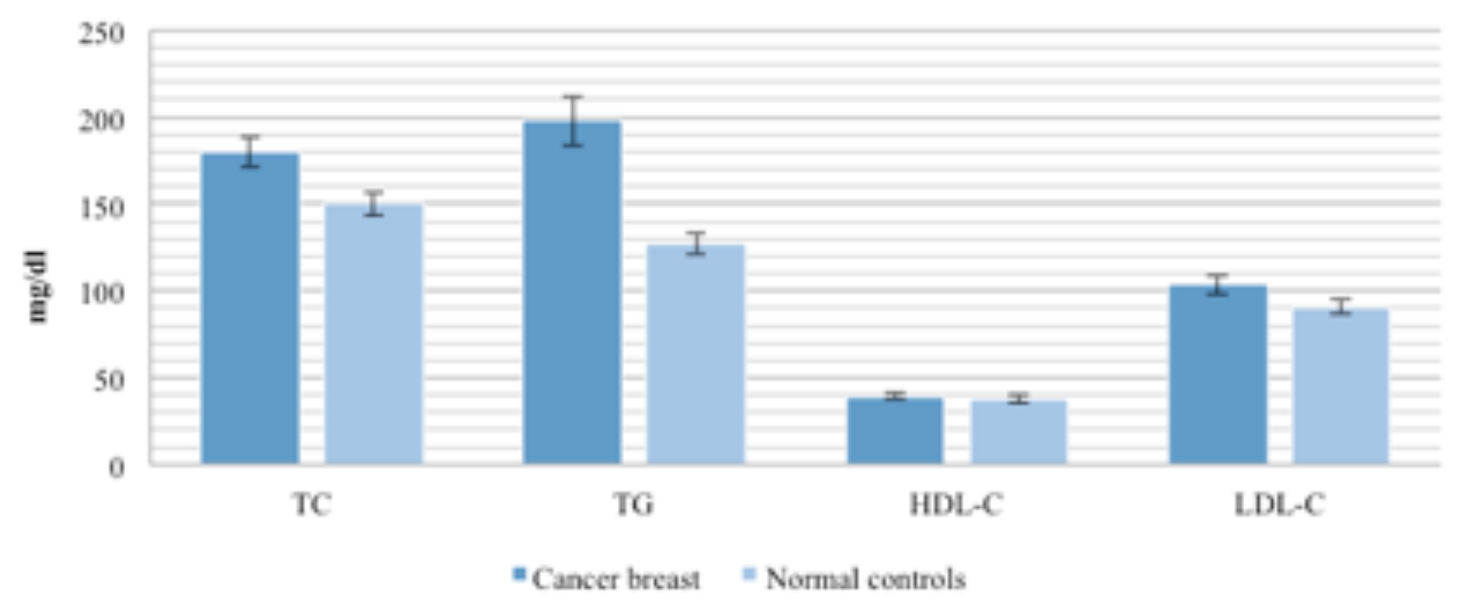

Figure 4. Pictorial representation of mean values of lipid profiles with standard error

profiles of carcinoma breast patients $(\mathrm{N}=125)$ with that of normal controls $(\mathrm{N}=70)$ and patients of benign breast diseases $(\mathrm{N}=30)$ found that $\mathrm{TG}$ were significantly elevated in carcinoma breast group in comparison to either of the control groups. ${ }^{23}$ And the levels of TC and HDL-C were significantly decreased in carcinoma breast group compared to normal control group. While there were no significant differences observed in other lipid parameters between the groups. In a case-control study by Pikul et al. which compared lipid profiles of carcinoma breast patients $(\mathrm{N}=249)$ with that of normal controls $(\mathrm{N}=154)$ found that TG, LDLC levels in breast cancer group were significantly higher than normal control group. ${ }^{25}$ However, TC level in breast cancer group was not significantly higher than the control group. The HDLC level in breast cancer group was lower than control group, but it was not statistically significant. Our study results are in coherence with that of the above mentioned studies with reference to TG levels, while significant changes in other lipid parameters were varied among different studies. The final results of the above mentioned studies are summarised in Table 6.

Considering the results of the study, there is definitely an association between carcinoma breast and altered lipid profile particularly TG levels. This paves the way for future studies to unveil whether there is a causative association between the altered lipid profile and carcinogenesis of the breast? If so can there be a role for desirable modifications in lipid profile for the prevention of carcinoma breast? Though our study has sufficient sample size, comparable baseline characteristics, appropriate selection of study and control groups to eliminate various bias factors, it is not devoid of limitations.

The main limiting factors of the study are, being a retrospective study design; no randomisation in sampling, there was no investigator blinding used, selection bias due to hospital-based subject selection. These can be addressed by applying appropriate epidemiological methods in future studies.

\section{CONCLUSIONS}

We would like to conclude that there is a significant alteration in lipid metabolism in carcinoma breast patients in comparison to normal controls. This should contribute to the future research to elucidate the relationship between altered lipid profile and carcinogenesis of the breast, enabling development of preventive strategies by means of desirable modification in lipid metabolism. We would like to recommend a well-structured prospective epidemiologically sound study, which can address the limitations of our study to establish a causative relation between altered lipid profile and carcinogenesis of the breast. 
To cite this article: Yalagachin G, Praveena S. A Retrospective Case-Control Study of Lipid Profiles in Carcinoma Breast in Comparison with Normal Controls. MJSBH. 2021;20(2):97-103.

Conflict of Interest: None declared

\section{REFERENCES}

1. Ferlay J, Soerjomataram I, Dikshit R, Eser S, Mathers C, Rebelo M, et al. Cancer incidence and mortality worldwide: sources, methods and major patterns in GLOBOCAN 2012. IJC. 2015 Mar;136(5):359-86. DOI: https:// doi.org/10.1002/ijc. 29210

2. Malvia S, Bagadi SA, Dubey US, Saxena S. Epidemiology of breast cancer in Indian women. Asia-Pac J Clin Oncol. 2017 Aug;13(4):289-95. DOI: https://doi.org/10.1111/ajco.12661

3. Zhang L, Li Z, Ding G, La X, Yang P, Li Z. GRP78 plays an integral role in tumour cell inflammation-related migration induced by M2 macrophages. Cell Signal. 2017;37:136-48. DOI: https://doi.org/10.1016/j.cellsig. 2017.06.008.

4. Pascual G, Avgustinova A, Mejetta S, Martín M, Castellanos A, Attolini CS, et al. Targeting metastasis-initiating cells through the fatty acid receptor CD36. Nature. 2017;541(7635):41-5. DOI: https://doi.org/10.1038/ nature20791.

5. Blücher C, Stadler SC. Obesity and breast cancer: current insights on the role of fatty acids and lipid metabolism in promoting breast cancer growth and progression. Front Endocrinol. 2017;8:293. DOI: https://doi.org/10.3389/fendo. 2017.00293.

6. Zhu Y, Aupperlee MD, Zhao Y, Tan YS, Kirk EL, Sun X, et al. Pubertal and adult windows of susceptibility to a high animal fat diet in Trp53-null mammary tumorigenesis. Oncotarget. 2016;7(50):83409. DOI: https://doi.org/ 10.18632/oncotarget.13112.

7. Wei LJ, Zhang C, Zhang H, Wei X, Li SX, Liu JT, et al. A case-control study on the association between serum lipid level and the risk of breast cancer. Chin J Prev Vet Med. 2016;50(12):1091-5. DOI: https://doi.org/10.3760/ cma.j.issn.0253-9624.2016.12.013.

8. Byon CH, Hardy RW, Ren C, Ponnazhagan S, Welch DR, McDonald JM, et al. Free fatty acids enhance breast cancer cell migration through plasminogen activator inhibitor-1 and SMAD4. Lab Investig. 2009 Nov;89(11): 1221-8. DOI: https://doi.org/10.1038/labinvest.2009.97.

9. Cheng C, Ru P, Geng F, Liu J, Yoo JY, Wu X, et al. Glucose-mediated N-glycosylation of SCAP is essential for SREBP-1 activation and tumor growth. Cancer cell. 2015 Nov 9;28(5):569-81. DOI: https://doi.org/10.1016/j.ccell. 2015.09.021.

10. Bao J, Zhu L, Zhu Q, Su J, Liu M, Huang W. SREBP-1 is an independent prognostic marker and promotes invasion and migration in breast cancer. Oncol Lett. 2016 Oct 1;12(4):2409-16. DOI: https://doi.org/10.3892/ol.2016.4988.

11. Jiang L, Wang H, Li J, Fang X, Pan H, Yuan X, et al. Up-regulated FASN expression promotes transcoelomic metastasis of ovarian cancer cell through epithelial-mesenchymal transition. Int J Mol Sci. 2014 Jul;15(7): 11539-54. DOI: https://doi.org/10.3390/ijms150711539.

12. Li J, Dong L, Wei D, Wang X, Zhang S, Li H. Fatty acid synthase mediates the epithelial-mesenchymal transition of breast cancer cells. Int J Biol Sci. 2014;10(2):171. DOI: https://doi.org/10.7150/ijbs.7357.

13. Wu X, Daniels G, Lee P, Monaco ME. Lipid metabolism in prostate cancer. Am J Clin Exp Urol. $2014 ; 2(2): 111$. PMID: 25374912.

14. Roberts MJ, Yaxley JW, Coughlin GD, Gianduzzo TR, Esler RC, Dunglison NT, et al. Can atorvastatin with metformin change the natural history of prostate cancer as characterised by molecular, metabolomic, imaging and pathological variables? A randomised controlled trial protocol. Contemp Clin Trials. 2016;50:16-20. DOI: https:// doi.org/10.1016/j.cct.2016.06.014.

15. Long J, Zhang CJ, Zhu N, Du K, Yin YF, Tan X, et al. Lipid metabolism and carcinogenesis, cancer development. Am J Cancer Res. 2018;8(5):778. PMID: 29888102.

16. Goldin BR, Woods MN, Spiegelman DL, Longcope C, Morrill-LaBrode A, Dwyer JT, et al. The effect of dietary fat and fibre on serum estrogen concentrations in premenopausal women under controlled dietary conditions. Cancer. 1994 Aug 1;74(S3):1125-31. DOI: https://doi.org/10.1002/1097-0142(19940801)74:3+<1125::aidcncr2820741521>3.0.co;2-5. 
17. Phipps AI, Buist DS, Malone KE, Barlow WE, Porter PL, Kerlikowske K, et al. Breast density, body mass index, and risk of tumor marker-defined subtypes of breast cancer. Ann Epidemiol. 2012 May 1;22(5):340-8. DOI: https:// doi.org/10.1016/j.annepidem.2012.02.002.

18. Pierobon M, Frankenfeld CL. Obesity as a risk factor for triple-negative breast cancers: a systematic review and meta-analysis. Breast Cancer Res Treat. 2013 Jan;137(1):307-14. DOI: https://doi.org/10.1007/s10549-012-2339-3.

19. Kelsey JL, Whittemore AS, Evans AS, Thompson WD. Methods in observational epidemiology. Second ed. Oxford University Press, 2001 Evans Road, Cary, NC 27513, USA; 1996.

20. Owiredu WK, Donkor S, Addai BW, Amidu N. Serum lipid profile of breast cancer patients. Pak J Biol Sci. 2009 Feb 1;12(4):332-8. DOI: https://doi.org/10.3923/pjbs.2009.332.338.

21. Nieman KM, Romero IL, Van Houten B, Lengyel E. Adipose tissue and adipocytes support tumorigenesis and metastasis. Biochim Biophys Acta Mol Cell Biol Lipids. 2013;1831(10):1533-41. DOI: https://doi.org/10.1016/ j.bbalip.2013.02.010.

22. Baumann J, Sevinsky C, Conklin DS. Lipid biology of breast cancer. Biochim Biophys Acta Mol Cell Biol Lipids. 2013 Oct 1;1831(10):1509-17. DOI: https://doi.org/10.1016/j.bbalip.2013.03.011.

23. Shah FD, Shukla SN, Shah PM, Patel HR, Patel PS. Significance of alterations in plasma lipid profile levels in breast cancer. Integr Cancer Ther. 2008 Mar;7(1):33-41. DOI: https://doi.org/10.1177/1534735407313883.

24. Dixit AK, Raza MA, Sharan J, Chauhan CG, Das B, Popat A. Serum Lipid Profiles in Breast Carcinoma and Benign Breast Diseases in Rohilkhand Region of Uttar Pradesh. IJSS. 2016;2(3):22-9. DOI: https://doi.org/10.17354/SUR/ 2016/23.

25. Laisupasin P, Thompat W, Sukarayodhin S, Sornprom A, Sudjaroen Y. Comparison of serum lipid profiles between normal controls and breast cancer patients. J Lab Physicians. 2013;5(1):38. DOI: https://doi.org/ 10.4103/0974-2727.115934. 